\title{
Repeat-Revolution: Forms of Partaker Agency in the Sound Works of Cage, Holmqvist and Bruys.
}

\author{
Saskia Isabella Maria Korsten \\ ArtEZ Institute of the Arts, \\ Amsterdam, the Netherlands \\ saskiakorsten@hotmail.com \\ s.korsten@artez.nl
}

\begin{abstract}
The works of composer John Cage and sound artist Nathalie Bruys will be coupled to my notion of partaker agency. The participatory aspects will be examined via Susanne Langer and Karen Barad helping to understand that sound has a vital form with its own agency. Supporting Cage's interest in sound as music, I will elaborate on the Buddhist kōan and Kototama chants. The tension between repetition regarded as similitude or difference, will be further examined via the works of Karl Holmqvist and Peter Handke. Arriving at the conclusion, via Jacques Derrida, that repetition might serve as a double mirror, opening up a way out of the realm of logic.
\end{abstract}

Repetition. Partaker agency. Participation. Sound. Double Mirror.

Every something is an echo of nothing

$$
\text { - John Cage }
$$

\section{SOUND PARTICIPATION.}

In August 1952 pianist David Tudor walked on stage at the Maverick Concert Hall in Woodstock, New York. He sat down before a piano with a stopwatch in his hand, placed the sheet music on top of the piano and did not strike a note in the whole performance. He premiered John Cage's composition 4'33" (1952). The piece is divided in three parts, with the only written instruction being the word tacet for each part. The work may be performed by an instrumentalist or combination of instrumentalists and last any length of time. Tudor performed the piece as follows: the first part in 33 seconds, the second part in 2 minutes and 40 seconds and the third part in 1 minute and 20 seconds, referring to the classical structure in music. The beginning of each part was marked by closing the lid of the piano and the end by opening the lid. The piece is a composition of chance in which everyincidental sound like someone coughing, or fidgeting on a chair, or a car passing by, becomes integrated in the performance. In Tudor's case all these chance-noises where exactly measured within the frame of real time within the duration of 4 minutes and 33 seconds by the sound of each second ticking away on his stopwatch. Each performance of 4'33" not only comprises of different performance choices, but also of different sounds being captivated within the duration of the performance. In this work duration is put forward as the musical characteristic. For Cage the material of music is sound and silence. Integrating these is composing.

Before elaborating on the participatory aspect of 4'33", it is apt to pursue the relation between the composer (via the score) and the performer first. In her Feeling and Form (1953), Susanne Langer writes about the experience of music. In chapter nine she specifically writes about the fact that once a composition is given to the world, different people are going to perform it (133). According to Langer, many musicians have maintained that there is no such thing as the piece, but rather speak of a class of pieces which have the notational devices of the score in common. According to Langer, someone silently reading music has to somehow imagine the tone in one's head. To do so, one needs to establish a living relation between the symbol and what this symbol would sound like fromthe 
memory of a bodily experience of this symbol as a sound. Langer explains this as follows:

This final imagination of tone itself, as something completely decided by the whole to which it belongs, requires a special symbolic support, a highly articulate bodily gesture; overtly, this gesture is the act of producing the tone, the performer's expression of it; physiologically, it is the feeling for the tone in the muscles set to produce it, and it is the symbol whereby the tone is imagined (138).

In Cage's case there is no notation of a tone which should be imagined while silently reading the score but rather a sense of space and time. The performer has to be able to read to score while performing it and simultaneously feeling his trained muscles ready to play the instrument before him. Yet, his action consists of marking certain moments in space and time, such as opening and closing the lid of the piano. The performer is alert to sensing the ambient sounds around him just as the audience is; the audience and the performer are united in this space-time score.

For Langer, the performance of a score is a new stage in music, whether it be the composer himself to perform the piece or someone else. The role of the performer is to carry on the commanding form as set out by the composer. She maintains that there should be a difference between the performer's own mental and emotional state and the emotional state asked for in the piece. The piece has its own mental and emotional subjectivity one has to tap into from an objective standpoint so to speak. "In the rich fabric of our own subjective existence we make discoveries, as we make them in the outer world, by the agency of adequate symbols. Through art we learn the character and range of subjective experience" (Langer, 146). The piece has to come to speak for itself and to be heard as itself, by means of its performance. Cage seems to take Langer's notion of music one step further into the realm of sound. Cage states that sound is music and explains in an interview that he particularly likes the fact that sound does not convey emotions or tell a love-story for instance, it simply is. He favors it for its chance, impersonal qualities, but also, importantly, because it is neither analytical nor emotional. "Sound," says Cage, "does not critique, interpret, or elaborate-it does not "talk."' He loves the sound of traffic seeping through the windows of his New York apartment because it is never the same, one cannot predict its progression. Cage actively engages all the environmental sounds in his composition of 4'33'.

A new participatory step is taken in 2014 when the John Cage Trust and Cage's long-time publisher, C.F. Peters launch a 4'33" App for iPhone and Android. Users are able to capture a three-movement 'performance' of the ambient sounds in their environment, and then upload and share that performance with the world. One is also able to listen to the performances of others, and to explore a worldwide map of evergrowing performance locations via the-world-of4'33"-function. In the library a recording of the ambient sounds at play in John Cage's New York apartment is featured as well.

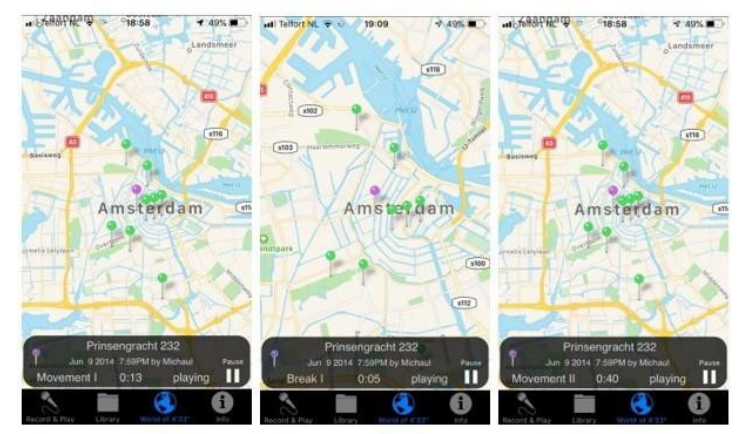

Figure 1: Screenshots from app 4'33" by John Cage Trust and C.F. Peters, 2014.

The uploaded recordings are structured as follows: Movement I: 0:00-0:30 Break I: 10 Movement II: 0:30-2:53 Break II: 10 Movement III: 2:53- 4:33 Complete: 4:33. During the two breaks the time of the score does not move forward, it holds at 30 seconds between the first and the second movement. After the break the second movement starts at 30 seconds. The break is displayed by a timer running backwards from 10 to 00 . In these two times 10 seconds no sound is recorded and no recorded sound can be heard in the play-modus as well. Awkwardly enough, it is precisely in these two times 10 seconds that the original manifestation of 4'33" can be best experienced. In these breaks, the real-time ambient sounds of one's actual environment are being heard within the specific duration of, in this case, 10 seconds. The passive registration or playing of ambient sounds of one's device stops and one turns to active listening instead. The app is a documentation device for previous performances which, in almost all cases, one has not attended. Although, it is interesting that one can listen to ambient sounds of places that one has never visited (in arctic areas for instance), it is not as participatory as a live performance of 4'33" can be. In the app one can secretly listen to ambient sounds of others in the 
comfortable domain of one's own house where one can cough freely instead of feeling the need to smother the cough in the inside of one's elbow. The two breaks of 10 seconds are as close as one can get to real-time participation in the 4'33" app, but new participatory aspectsare introduced in this app. There are more agencies involved than in 1952, now it is not only the context of the concert hall, score, performer and audience, but there is also the registering device, the software, the database, Internet connection, membership, storage etc. In the next part I will travel from participation in Cage's 4'33" toward the more contemporary notion of partaker agency.

\section{PARTAKER AGENCY}

To introduce the term partaker agency it is needed to take a step back towards the first conception of the term partaker by art historian Alexander Dorner. In 1947 John Dewey has written in the introduction of AlexanderDorner's The Way Beyond Art (1947) about Dorner's new outtake on the idea of a person as an individual following from the lineage from the individualas a fixed element in a given larger whole towards the idea of "The Individual" as fixed in himself.

\section{Against these fixations, Dr. Dorner points to the personal individual as partaker in the "general process of life" and as a "special contributor to it." This union of partaker and contributor describes the enduring work of the artist (10).}

Dorner establishes the personal individual as a partaker holding certain responsibilities towards life. In her Aesthetics of Interaction in Digital Art, art historian Katja Kwastek describes Cage's 4'33" as one of the first examples of audience participation.

Thus, audience participation was first realized in terms of a presence of the recipient "in the work" with the aim of enhancing (self-) perception (13).

With audience participation a new sort of spectator is born. In his article Reversing the Spectator Paradigm, Raivo Kelomees describes how since the 1990's the roles of spectator and participant in the art contexthave been under discussion. He sums up different concepts for this 'new' spectator: "viewer, consumer, user, spectator, observer, active participant, vuser ('viewer/user'), immersant, spect-actor, interactor, executor, (co)creator, viewer- interactor, receiver-participant, viewerperformer" (3). The new ascribed roles for the spectator reflect on the changed position of the viewer but do not so much reflect on the changed position of the artwork. Does the artwork participate as well? Or what are the other agencies participating? I will now further enquire the role of what I have coined partaker agency in 2018 in an article called Partaker Agency: Entanglement of agencies in artworks by Bekirovic and Abramović. Partaker agency is understood by me as the agency at work in collaborations between the various entities within an artwork in its coming to 'life.' it is at work in the very first conception of the artwork, during the process of making, and until and beyond the interaction with the audience. This whole process is, following the title of an article by physicist Karen Barad, "how matter starts to 'matter'" (Barad).

In the case of contemporary Dutch sound artist Nathalie Bruys partaker agency is extant. Her work Frequency Elixer (2009) is an interactive Soundsculpture of twenty meters long and positioned on the wall in the New Music House in the city of Utrecht. It is a white wall-relief with a touchscreen and six speakers integrated in it.
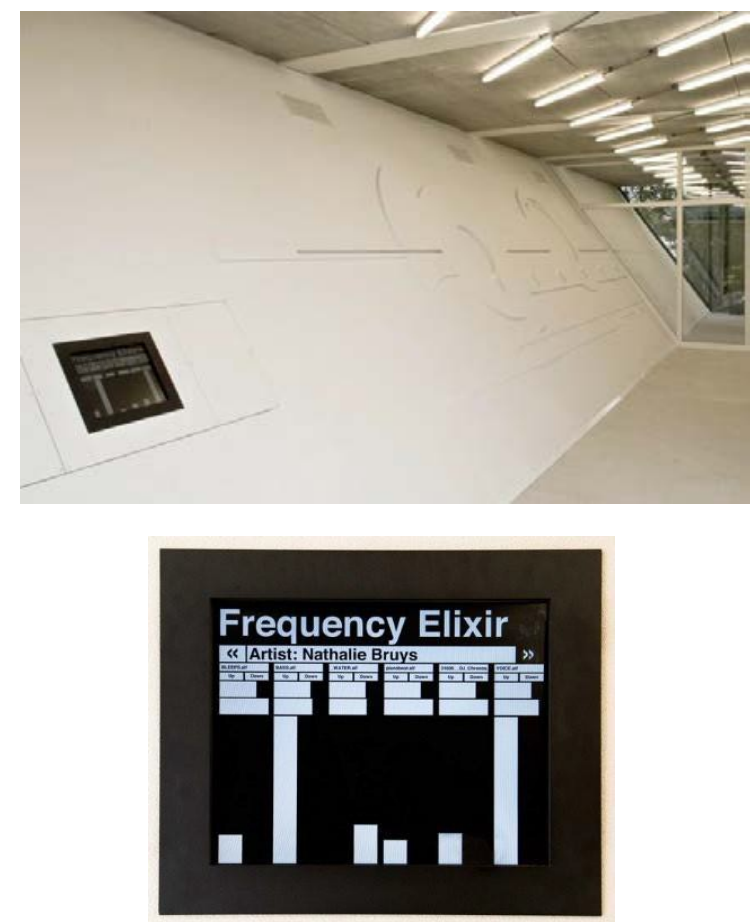

Figures 2 a, b: Nathalie Bruys, Frequency Elixer (2009), overview (left), detail interface (right).

Special software has been written to select samples for every one of the six different channels to be played on each executive speaker. The samples are uploaded by musicians who have previously performed at the New Music House. The samples are continually updated after each new 
performance of musicians. The visitor of theNew Music House is able to mix the samples and create one's own Soundcloud to be played over the 6 channeled speaker system. It is a participatory score in which the musicians, the visitor and the computer software each play a part. Just as Cage likes the idea of impersonal sounds, Bruys in a way, impersonalizes the input of the musicians as a sample, deprived of its initial context, to become sound. Maybe even meaningless sound, ready to be mixed inside a new temporal context. Meaning might be injected in it again by mixing them together or it might not. It is easy to assume that a visitor is not an expert on the enormous database of samples and so the software plays a big role in in-forming the visitor in its usage of it. The software molds the interactor in the work; the software can be regarded as a participating agency. Kwastek has already noted that the incorporation of participatory elements are accompanied by considerations about how these processes could be controlled (18). A paradox arises: in order to guarantee indeterminacy in the interaction, precise game rules should be provided (19). In Bruys' case the software program guarantees a flexible score to be co-composed by a visitor. The software has an agency that takes part in the artwork's process. In her work, all the agencies participating hold a certain responsibility, so to speak, towards the end result of the participation. For the non-human agencies, it might be strange to speak of responsibility. The same goes for terms as collaboration and participation. Symbiosis might be a more appropriate term. In the symbiosis, each acting component plays a crucial part.

\section{THE THING NOT THE WORD}

Now that the participatory aspect is established, this part will go into the content of the case studies in order to get to the strategies employed by the artists to engage participants in their work.

With the acceptance of chance in his works Cage enters the domain of Zen Buddhism. In his book Silence (1961): "Every Something is an Echo of Nothing. (131)" Cage is interested in terms as nothing and meaninglessness to somehow prove their real existence.

Cage's contemporary Paul Wienpahl (1916-80) has written [...] "The positivist arrived at meaninglessness on the intellectual level - and shied away from it. The Buddhist heads into it, takes the next step to it on the physical or nonverbal level. The positivist got to the notion of meaninglessness. The Buddhist gets to the thing" (138). Wienpahl explains this via an example of a Buddhist kōan. This is a seemingly meaningless question with which a beginner in Zen study can sit. An example of such a kōan is: "Does a dog have Buddha nature?" To which Jōshu replied: "Mu." The Japanese word mu means no, nothing, none, emptiness, depending on the context when translated into English.

(136) Sitting with the kōan can last for days and one reports to the rōshi (the teacher) once or twice a day. Sitting in this Buddhist manner is called Zazen.

[...] Now what? It seems that there is nothing you can say. For now anything that you might say will have some connection with the kōan. Say nothing, then. But that is logical, too. You can see the logic in that move. So, there is nothing (sic) you can do. You are caught. It is an impasse. How can you do nothing? Here is a break. It is as though something else intervenes. The day comes when you say nothing. You do not say nothing, so to speak. You just cannot say anything. You are silent, not as a result of deliberation or deliberately. You say nothing because no words will come-not for a reason but from a cause (Wienpahl, 143).

A statement or question that is logically meaningless can still have a use. Since, in common-language philosophy based on Wittgenstein, we discover a world's meaning in its use, a kōan, being useful, can therefore mean something even if that meaning lies outside the realm of logic (Cage, from the foreword by Kyle Gann, p. xviii-xix). Wienpahl arrives at the conclusion that "mu" means mu, not "mu."
"Mu" means not a word but a thing. How do you transcend logic? By going beyond words. By going from the words to the things [...].Therehas been all this talk of meaninglessness. What is this thing - meaninglessness? Why should there not be such a thing as well as the word (Wienpahl, 143)?

In his Lecture on Nothing Cage puts it like this: "I have nothing to say and I am saying it" (109). It makes sense to think of 4'33" as a Zen exercise. Cage also adheres to a story by the Zen Master Suzuki rōshi. In a 1968 lecture, the Zen master tells the following story of Seiko: There was a man named Seiko, who loved dragons. He designed his house like a dragonhouse, and he had many pictures of dragons. So the real dragon thought, "If I appear in his house, he will be very pleased." So one day the 
real dragon appeared in his room and Seiko was very scared of it (he drew his sword and almost killed it) (archive of Suzuki rōshi). The lesson in this might be to not become so accustomed to images or words that one is dismayed by the real thing itself.

Cage quotes Meister Eckhart warning for the wrong imitations:

\begin{abstract}
Imitating either oneself or others, care should be taken to imitate structure, not form (also structural materials and structural methods, not formal materials and formal methods), disciplines, not dreams; thus one remains "innocent and free to receive anew with each Now-moment a heavenly gift" (64).
\end{abstract}

Every performance of 4'33" is a new Nowmoment in which the audience seems to be facing the real thing. Wienpahl at the end of his article arrives at the conclusion of the zazen mediation of the kōan and explains that:

\begin{abstract}
It is thing $-m u-$ you are working with now. $M u . M u$. $M u$. You are trying to become $m u$, at first by saying " $m u$," and then by gradually getting beyond the question and anything that you might say about it. You see its meaninglessness and thereby meaninglessness. "Meaninglessness" has ceased to be opaque and has become transparent. You see through it to the things (144).
\end{abstract}

In this state of Zazen one might be able to finally see every something as an echo of nothing as Cage would state it. In Cage's case each Nowmoment of every performance of 4'33" is an experience of meaninglessness. The score of 4'33" is a structure and not a form to be copied. Cage did not prescribe with what instruments or with how many instruments one should perform 4'33", he did not even prescribe the duration: the duration can be any length of time. 4'33" is a moment of sounding all things together in a certain timeframe. He lets the listener experience music directly. As Kahn states: "Cage wants to get to the thing, which lies outside the realm of logic" (Cage, xix).

\section{THE WORD AS THE THING}

Now that via Wienpahl a thing apart from the word is introduced I would, contradictory, like to turn my attention to the usage of words in music and sound art with playwright Peter Handke and contemporary poet Karl Holmqvist as case studies. Holmqvist acknowledges the power that words have. he says "There seems to be a kind of respect for language. People are afraid to misspell something or do something wrong"(In an interview for Camden Art Center). It is also reflected upon in the following lines in his book ' $K$ : "WORDS ARE PEOPLE. LANGUAGE IS POWER." "WORDS ARE PEOPLE. THOUGHTS ARE PEOPLE. LANGUAGE IS POWER." "WE MAKE MAGICS WITH OUR MINDS..." "RIGHT?" $(4,6,8,10)$.

Langer has written about the usage of words in music. She says:

What all good composers do with language is neither to ignore its character, nor to obey poetic laws, but to transform the entire verbal material sound, meaning, and all - into musical elements. When words enter into music they are no longer prose or poetry, they are elements of the music (150).

Cage has also pondered over the question of the role of words in music. He says: "If words are sounds, are they musical or are they just noises? If sounds are noises but not words, are they meaningful? Are they musical (65)?" The motto of Holmqvist's book ' $K$ reads: "ma non è cosi: è musica" translated freely as "It is not like that: it is music." Holmqvist relates to Langer in his liberating of words or even phrases out of the language system to make them into something else. He says: "I am interested in taking things that are readily identifiable and reshuffle them and create something different; [...] [the] idea of reshaping reality according to some other rule or system."

Holmqvist even questions the understandability of words.

No one really knows how language travels from one person to another. So there is an instance of magic, or witchcraft I would say, in how you take your message out there and how it is caught up, misunderstood for sure but understood in some sense and then people will make of it whatever they can. That's the hex, I guess, of the text (interview Holmqvist).

Going back in time, I would like to introduce yet another contemporary of Cage, playwright Peter Handke with his play Kaspar (1968). The main character in Kaspar is inspired by the figure of Kaspar Hauser who was held in a cellar in Germany for approximately 16 years and then brought outside in the streets in 1828. He was said to only have spoken one sentence and he 
could hardly walk. Numerous people took care of him and taught him how to read and write. Handke's Kaspar is also about a boy who cannot speak more than one sentence and seems not to relate to objects surrounding him; he awkwardly bumps into chairs and tables. Handke introduces Einsagers (translated by literary scholar Bettina Knapp as "insayers," and, by implication, "indoctrinators") who are likely inspired on historical figures who tried to educate Kaspar Hauser. In the play they are trying to bring Kaspar to speech through speech (249).

Subtle teachers, the Einsagers take the initiative. They label each object, thereby identifying it with the word, then inform Kaspar of its function. By means of word-forces and word-manipulation, they teach him all the stereotypes and platitudes that make society society and culture culture. (Knapp, p. 253)

Knapp explains that for Handke, theater has neither object nor subject. In Peter Handke's Kaspar words alone are important; they alone create reality. Since these Einsagers have no bodily character on stage (they are only voices to be heard), the words become only sounding entities indoctrinating Kaspar. In Handke's play, initially, Kaspar can only repeat his one sentence: "I want to be a person like somebody else was once." Slowly, Kaspar gains the ability to speak and as such the power to control also the objects he now knows how to name. He now can distinguish himself from his surroundings and simultaneously, he loses his sense of belonging in this surroundings. According to Knapp, Kaspar's ego, originally, could not be distinguished as something apart from its surroundings. "Ego and non-ego (or self, the total psyche), then are one and the same, as are inner and outer worlds. Existence is lived on the basis of a single totality. Like an infant or child, Kaspar exists in an original state of wholeness: an ouroboric condition" (249). The word Ouroboric is identified with the image of the taileating serpent. The ouroboric state exists prior to the birth of consciousness. Relating this back to the notion of participation, one could state that in order to partake one should become entangled in the performance but one should also be able to recognize one's own agency apart from other agencies to becomeconscious about the performance taking place.

Functional systems of signification, are nonexistent in Kaspar. Handke might be holding a position at the other side of the kōan-coin. For Handke only words are acceptable, not what they signify. This holds a similarity with Cage's idea of sounds being impersonal; a sound is what it is in itself. Both Cage and Handke try to get to the thing itself which is not the symbol for it. Maybe one could say that Handke is concerned with the word as a thing in and of itself.

$$
\begin{aligned}
& >\text { The Thing, not The Word - Zazen, the kōan } \\
& \text { kōan-coin, two sides - } \\
& >\text { The Word as The Thing - Handke's Kaspar }
\end{aligned}
$$

Table 1: the kōan-coin exemplified.

\section{RE-SOUNDING RESPONSIBILITIES}

Langer already noted that the origin of song is probably the intonation of words, to make them more potent in prayer or magic (149).

In the ancient Japanese tradition of Kototama sound meditations are based on repetitive sounds and rhythms which hold a performative power. Kototama means "spirit of language", "sacred sound", or "the knowledge of the vibration of the Universe." It is the practice of generating ritual sounds and words and is practiced within the martial art form of Aikido. The word Kototama literally means: "word" and "soul or spirit." Aikido instructor Jack Wada explains it as the spirit of the universe expressed in sound. The Kototama principle is the principle of life as taught by $O$ Sensei Ueshiba, the founder of Aikido. It is based on sounds as religious instruments and agents. In the re-sounding of sounds a world can manifest itself; the sound generates a coming to life.

Wada explains that $O$ Sensei said that these sounds generated, activated and sustained what he called creation. Wada thinks that he was looking past the obvious physical universe into "almost an energy blue print for creation." In Inochi, The Book of Life (1984) the principles of Kototama are extensively explained by Sensei Nikoto Masahilo Nakazono. The Kototama holds fifty life rhythms, including five mother sounds combined with ten father rhythms. According to Sensei Nakazono these rhythms open one up to the highest human capacity.

The manifestation of human life, both body and spirit, is the activity of total human life in a priori universe: Human = Universe. Human life is the universe itself; this explanation of our life is the basic premise of the Kototama Principle (2). 
Here another step can be taken to understand the division between the word (or in this case: the sound) and the thing. It seems that the division is needed to bridge the gap between the two in order to make them one again.

The vibration of Mana, the rhythm itself coming out as sound, is Kana, the Word of God. Spoken this way, Kana is heard by the ear and the sound is sent back to Mana. That sound rhythm, synchronizing with the brain rhythm, meshes perfectly, making them one(8).

Langer has defined as the elements of music not tones of such and such pitch, duration and loudness, nor chords and measured beats; "they are, like all artistic elements, something virtual, created only for perception. Eduard Hanslick denoted them rightly: "tönend bewegte Formen" - "sounding forms in motion"' (107). The Kototama chant creates a resonant torus around the body. Sound, seen this way, almost becomes an object.

Bruys has also worked with cosmic vibrations in her work. Her Galactic $C$ omputer $P$ ortal Machine (2011) is a sound sculpture on a cemetery in Amsterdam. Inside a small oneperson building, one is exposed to these cosmic vibrations. A composition is made by tuning forks with Solfeggio frequencies such as the $528 \mathrm{~Hz}$ (DNA) frequency. A specially designed analogue mechanism strikes the tuning forks. On her website Bruys writes that

[t]hey are tuned to the solar system forming a key to the universe. The frequencies were banned by the church but are to be heard in Gregorian chants and old mantra's. They were used to gain access to deeper levels of other dimensions and subconsciousness. The $528 \mathrm{~Hz}$ frequency is used in laboratories for genetics in order to reunite shattered genes (from Bruys' website).

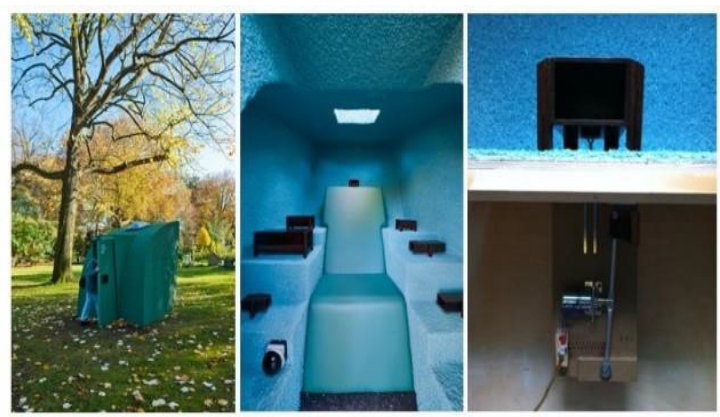

Figures 3 a, b, c: Nathalie Bruys, 'Galactic Computer Portal Machine’ (2011).
Bruys strongly believes in the healing quality of the vibrations. In the little building for one, the body is positioned between the forks and enters in an active relation with them. One thing that the participatory works of Bruys and Cage have in common is that the agencies partaking, have a certain responsibility to act. In Cage's case the audience can decide to leave, to stay and be as quiet as possible or to stay and be noisy, either way, one has to decide on some kind of action towards the piece. Kwastek pointed out that audience participation was aimed at (self-) perception (13). She meant this (self-) perception for the human audience. However, the more classical conception of the audience as a group of passive spectators has changed since around the time of Cage's 4'33" and every viewing act has come to be perceived of as more or less interactive in the sense that in the act of viewing a relation is established between viewer and viewed. This can be read as a collaboration between object and viewer to form a live-like percept. In Dorner's account an event proceeds from a total process. Fact to him is that which is done. Event and fact enter together as inceptions of new events and new things to be done. Barad states that there are ever changing possibilities to act and that these possibilities entail a responsibility to intervene in the world's becoming. Barad calls this agential realism. Barad states that objectivity implies being accountable to marks on bodies. To accept the fact that phenomena are made up of components intra-acting, means accepting that one cannot collapse inside oneself in some sort of vacuum but one is always entangled in an event with other agencies. This way subjectivity and objectivity become ever-changing positions and agencies are partaking in this continuous shifting of positions.

[...] [A]gency cannot be designated as an attribute of 'subjects' or 'objects', it is 'doing'/'being' in its intra-activity (Barad, 827).

In the experience of Kototama and in the work with the tuning forks by Bruys, Barad's ideas become tangible. Looking back, Cage might adhere to this logic as well as he invites the audience to become part of the performance and how he invests them with a sense of responsibility to at least become aware of oneself at that particular moment in time. Simultaneously, he creates room for random sounds from the stage and from the surroundings of the performance location to become part of the performances alongside the sounds made by the performer and the audience. He states that "[...] humanity and nature, not separate, are in this world together; that nothing 
was lost when everything was given away. In fact, everything is gained" (8). Bruys and Cage randomize sounds in order to give way to chance compositions that find new meanings in every new context, in every new interaction or intra-action.

\section{REPEAT-REVOLUTION}

In his article Herhaling $v$ ersus $V$ ooruitgang (Repetition versus Progress) (2009) media theorist Boris Groys separates two forms of experiencing religion by distinguishing between interpretation and material form. A religious fundamentalist, according to Groys, is a person who believes in the primacy of the letter over the spirit. He sees to the correctness of the ritual rather than to being faithful to the truth (24). Groys defines two forms of repetition within religious experience:

(1) Iteration of the spirit and in the spirit, for instance the repetition of the true, inner essence of a religious message; and (2) the repetition of the outer form of a religious ritual. [...] The first is mostly being regarded as the real repetition, as the authentic, 'inner' continuation of a religious tradition, a continuation simultaneously presuming a breach with the sheer outwardly directed, conventional, coincidentally grown form of the same tradition - or even demanding such a breach (24).

This holds a relation to Eckhart's quote by Cage that one should imitate structure, not form. Holmqvist is interested in "[...] types of slogans and catchphrases and things that capitalist society tends to repeat within a tendency to try and engrave things on you and how you have these sale slogans and different kinds of messages on repeat in your mind"(Interview at Camden Art Center). Groys perceives of a discord between what he calls consumers of religious rituals and the producers of knowledge who actively provide interpretations of religious texts. Holmqvist seems to critically play with his role as a consumer of capitalist texts in order to make one aware of them or to consciously alter the system in which these texts circulate and operate.

There have been countless studies of rhythm, based on the notion of periodicity, or regular recurrence of events says Langer. The ticking of a clock is repetitious and regular, but not in itself rhythmic; the listening ear hears rhythms in the succession of equal ticks, the human mind organizes them into a temporal form. (126)
Breathing is the most perfect exhibit of physiological rhythm: as we release the breath we have taken, we build up a bodily need of oxygen that is the motivation, and therefore the real beginning, of the new breath. (127)

For Langer rhythm through repetition is vital since every new breath, is exactly that: a new breath. It is not a copy of the former breath although it may resemble it closely. It is not a literal repetition of the form of one breath but it is the repetition of the structure of breathing. For Holmqvist iteration is a vital strategy to reshape a language system. His poem ONE IS NOONE consists of twenty pages repeating the same sentence "ONE IS NO ONE" iterated over and over again. If one recites this poem, at a certain point one starts to struggle with the rhythmic sequence and starts to say: "NO ONE ONE IS NO ONE." Also misreadings occur. Such as: "ONE ONE IS NO ONE" or "IS NO ONE ISNO ONE" and the like. The wrong rhythmic version can be also read as: "NO ONE "ONE" IS NO ONE" and then be associated with the kōan playing with the different notions of "ONE" and ONE quite similarly as the notions of "mu" and mu. It holds a comparison with what Cage in an interview has explained via two Coca-Cola bottles:

If I look at a Coca-Cola bottle and then look at another Coca-Cola bottle, I want to forget the first bottle. In order to see the second as being original and it is original because it is in a different position in space and time and light is shining on it differently, so no two Coca-Cola bottles are the same.

To me, this stills holds if I copy a digital image of a Coca-Cola bottle and position the two of them next to each other on the page. They are on different positions and since I can see both of them simultaneously, they cannot be one:
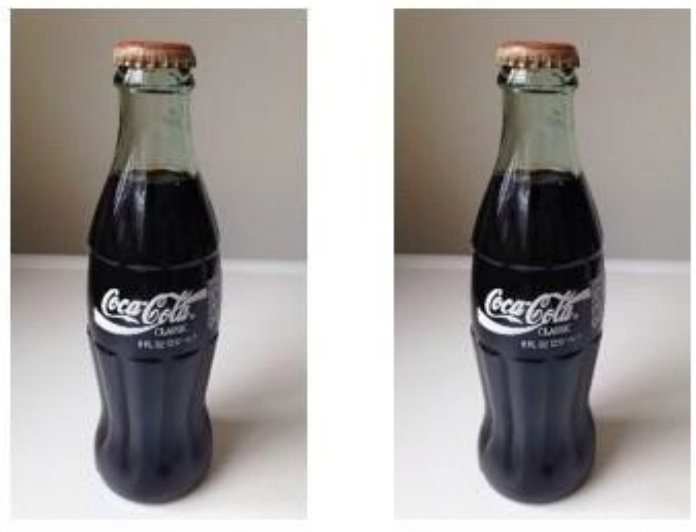

Figures 4a, b: Copied images of Coca-Colabottles from the fifties 
Cage uses the Coca-Cola example to explain what he calls "not wanting to remember." Some Zen masters say that when one stands on one leg, one should forget the other leg. This means taking it step by step. This is true practice. If one sticks to both right and left leg, walking is not possible since one remains in the same position (from the Suzuki Rōshi archive). One could argue that in order to walk one has to experience a new foot every time, since it is in a new position and forget the old foot in the old position. It sheds yet another light on Holmqvist's ONE IS NO ONE, in the sense that every ONE is indeed NO ONE since it is another ONE positioned slightly further along the line in the poem. There is an imitation of structure in this poem but not an imitation of form since every ONE is a new ONE. Looking at it from this perspective it holds a comparison to Handke's idea of a word being precisely that: a word. If the same word is repeated over and over again, that word is always a new word since it only refers back to itself. It adheres to computer code as well. The code is comprised of similar ones and zeros over and over again, yet every single one and zero is similarly important in adding up to a specific outcome, the exact position of each one and zero is crucial. Another example of iteration is exemplified by artist duo Korsten \& De Jong. In their work Back-Space ( or t he Maze o $f$ Punctuation) (2017) they play with the notion of rhythm and repetition in text as well.

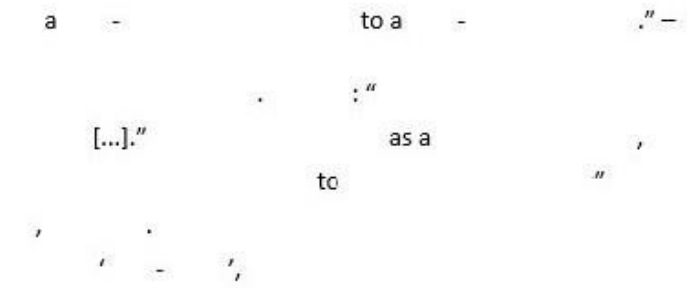

Figure 5: screenshot Korsten \& De Jong 'Back-Space (or the Maze of Punctuation),' 2017.

Live, De Jong whitens the words in a text according to the following rules: first names, then nouns, then adjectives, then verbs and the last words being whitened are articles, prepositions and conjunctions. Meanwhile, Korsten repetitively recites the text remaining on the screen. Interestingly, when names and nouns are made invisible, the text starts to fall apart. No clear intonation can be derived from only articles, prepositions and conjunctions. Korsten starts to sound more and more computerlike and a rhythm emerges. Especially, the remaining 'a's' obtain a persistent agency whereas they wouldnormally hold a subservient position in a text. The punctuation marks are left as the silent structure of a text. Barad speaks of exteriority-withinphenomena and it is through specific agential intra-actions that the boundaries and properties of the components of phenomena become determined. It is through Korsten \& De Jong's intra-acting with the text that these boundaries become visible and room is generated to fill the space between these punctuation marks with other text or move the punctuation marks to new positions.

The creation of conversing artificial intelligence has similarities with how Kaspar is brought to speech. The usage of language in a meaningful way is one of its goals. Bruys questions the part the computersoftware plays in her work. In her I am you, the speaking voice calls out: "Fuck you robot, you don't even understand me." Holmqvist performs his poems computer-like: as a form of code. In his work NUMBERS he declares repeatedly: "ONE, TWO, IT'S MORE FUN TO COMPUTE." How his texts are composed of samples of human conversation, song lines, slogans, and adverts, resembles the way a chatbot would compose a conversation. He uses only capitals as to eliminate hierarchy and a form of context in words, bringing them back to monotonous equals. Holmqvist performs robotlike, he is human becoming a computer. On the other hand, Kaspar in Handke's play, starts to act human while he seemed robotlike to start with. Holmqvist let's agency seep through in his usage of selective repetitions of given sentences and words, a bit like how Echo in Ovid's metamorphoses speaks by repeating the last words spoken by others. Kaspar loses his agency while slowly being encapsulated in a language system, Holmqvist might become a modern alter ego for Kaspar finding his way out of the language system again. Gaining control over his agency by undoing language of its functions and refunctioning them again via subverted repetitions of parts of it. Simultaneously, Holmqvist is handing an exit out of a language system for the participating audiences. His works are put as imperatives, they incent an action in its reading. Like Echo, he can only use given phrases to distort them in the way that allows him to free them from their meaning and alter them in performative new options.

\section{OSCILLATING INTRA-ACTION}

Groys uses Gilles Deleuze's text Différence et Repetition to make a point about the danger of literal repetition as something radically artificial and contravening everything living including laws of physics and moral laws (25). According 
to Groys also Walter Benjamin has spoken of a revolution being a breach of continuity(25). At the end of Handke's play, Kaspar utters: "Goats and monkeys" five times, topples and then falls behind the curtain (Knapp, 258). One could regard this as a form of literal repetition and as such might serve as a break with the continuity of life. Kaspar now knows how to use language but he has completely lost the sense of it at the same time.

To elaborate the question of similarity of, for instance ONE and NO ONE and Cage's CocaCola bottles, Derrida's notion of Différance cannot be omitted. Différance in its new spelling is neither a word nor a concept to him; he insists on the word assemblage (in the reproduction of his article: 280).

The verb "to differ" seems to differ from itself. On the one hand, it indicates difference as distinction inequality, or discernibility; on the other, it expresses the interposition of delay, the interval of a spacing and temporalizing that puts off until "later" what is presently denied, the possible that is presently impossible. [...] In the one case "to differ" signifies nonidentity; in the other case it signifies the order of the same. [...] We provisionally give the name différance to this sameness which is not identical: by the silent writing of its $a$, it has the desired advantage of referring to differing, both as spacing/temporalizing and as the movement that structures every dissociation (255).

Artists like Holmqvist employ rhythmic, repetitive and durational strategies to lure the reader/listener/performer into their works. It causes one to oscillate between the form of the work and its structure. The work then functions like a double mirror, referring to a looking glass that is both transparent and reflective. Wienpahl concluded that if one finally experiences "mu" as mu, one looks through the word to the thing. The word becomes transparent so to speak. This relates to Ovid's Narcissus gazing at his own similitude in the pool and introduce the double mirror. Would it then be possible that his mirror-image stares back at him from underneath the surface, through the transparent side of the mirror? "Mu" looks at mu and they might be regarded as united in a form of oscillating intra-action; different but the same. There is a continuous oscillation at hand from "mu" to mu and from ONE to NO ONE. In the middle they meet.

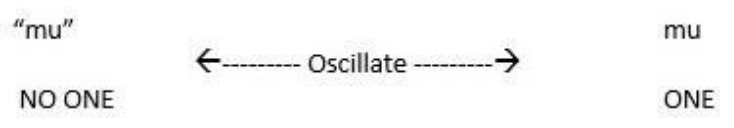

Table 2: Oscillation exemplified.

Derrida's a is positioned at the fulcrum of the word Différance and highlights the fact that it can mean two things simultaneously. "Différance is not simply active [...]; it rather indicates the middle voice, it precedes and sets up the opposition between passivity and activity (279)." And "[t]he a of différance [...] is not heard; it remains silent, secret, and discreet, like a tomb" (280). Through the silent a the one meaning is able to resonate in the other.

It has become clear that repetition is hardly ever literal and actually holds performative powers. In the Kototama ritual the sounds or words are separated from the thing that they signify; subsequently they are reunited in the active resounding of the sounds in the chants. In this resounding they find their significance every time anew. In every chant the world actually manifests itself anew. Holmqvist shows that even in a world where one only has two words (or numbers) at one's disposal, one can say numerous original things with them when one actively engages in refunctioning them again and again. The last word goes to Cage explaining the function of silence as liberating sounds from meaning and opening up the possibility to intra-act with what he calls the thing outside the realm of logic.

[...] Where these ears are in connection with a mind that has nothing to do, that mind is free to enter into the act of listening, hearing each sound just as it is, not as a phenomenon more or less approximating a preconception $(22,23)$. 


\section{REFERENCES}

Barad, K., 2003. Posthumanist Performativity: Toward an Understanding of How Matter comes to Matter. Signs: Journal of Women in Culture and Society, 28(3), pp. 801-831.

Bruys, N., 2000. aka KODI, I am you https://soundcloud.com/spiripirate/i-am-youkodi. (Accessed August 2019).

---., 2009. On her website Frequency Elixir: http://www.nathaliebruys.com/installations/fr eq uency-elixerl. (Accessed August 2019).

---., 2011. On her website Galactic Computer Portal Machine :

http://www.nathaliebruys.com/

installations/galactic-computer-portal-machine/ (Accessed August 2019).

Cage, J., 1992. An interview with John Cage as part of the documentary Écoute, directed by Miroslav Sebestik https://vimeo.com/23081468. (Accessed August 2019).

---., 2013. Silence. Middletown: Wesleyan University Press.

Derrida, J., 1968. Differance. Bulletin d e la Societe francaise de philosophie, JulySeptember, LXII(3), pp. 73-101.

Dorner, A., 1958. The Way Beyond 'Art'. New York: New York University Press.

Groys, B., 2009. Herhaling versus Vooruitgang (Repetition versus Progression). Now is the Time, pp. 20-29.

Holmqvist, K., 2012. 'K. Bergen: JRP Ringier.

---,. 2018. NUMBERS performed at Spike

Berlin.

https://www.youtube.com/watch?v=bblyMC9B

7zM (Accessed August 2019).

---,. 2019. Interview at Camden Arts Centre https://vimeo.com/163537925. (Accessed August 2019).

Kelomees, R., 2019. Reversing the spectator paradigm: symbiotic interaction and the 'gaze' of the artwork. Digital Creativity.

Knapp, B., 1990. Peter Handke's Kaspar: The Mechanics of Language-A Fractionating Schizophrenic Theatrical Event. Studies in 20th Century Literature, 14(2), article 8.
Korsten, S. I. M., 2018. Partaker Agency: Entanglement of agencies in artworks by Bekirovic and Abramović. Politics o ft he Machines.

Kwastek, K., 2013. Aesthetics of Interaction in Digital Art. Cambridge: MIT Press.

Langer, S., 1953. Feeling and Form. New York: Charles Scribner's Sons.

Massumi, B., 2007. The $T$ hinking $F$ eeling of What $H$ appens. Rotterdam: V2_Publishing/NAi Publishers.

Nakazono, N. M., [1979], 1983. Inochi, The Book of LIfe. Santa Fe: Kototama Institute.

Suzuki Rōshi. Online archive on: http://suzukiroshi.sfzc.org/archives/index.cgi/68

1012BV.html?seemore $=\mathrm{y}$ (Accessed August 2019).

Wada, J., in the video Kototama Chant - Jack Wada.

https://www.youtube.com/watch?v=buSKwZWI Lig (Accessed 14 August 2019).

Wienpahl, P., 1965. On the Meaninglessness of Philosophical Questions. Philosophy East and West, April.15(2).

I would like to thank professor Peter Sonderen of the ArtEZ professorship Theory in the Arts for commenting and reviewing my text. 